\title{
Loci controlling lymphocyte production of interferon $\gamma$ after alloantigen stimulation in vitro and their co-localization with genes controlling lymphocyte infiltration of tumors and tumor susceptibility
}

\author{
Marie Lipoldová · Helena Havelková · Jana Badalová · Jarmila Vojtíšková · \\ Lei Quan · Magdaléna Krulová · Yahya Sohrabi · Alphons P. Stassen • \\ Peter Demant
}

Received: 5 February 2009/Accepted: 2 July 2009/Published online: 5 August 2009

(c) The Author(s) 2009. This article is published with open access at Springerlink.com

\begin{abstract}
Low infiltration of lymphocytes into cancers is associated with poor prognosis, but the reasons why some patients exhibit a low and others a high infiltration of tumors are unknown. Previously we mapped four loci (Lynf1-Lynf4) controlling lymphocyte infiltration of mouse lung tumors. These loci do not encode any of the molecules that are involved in traffic of lymphocytes. Here we report a genetic relationship between these loci and the control of production of IFN $\gamma$ in allogeneic mixed lymphocyte cultures (MLC). We found that IFN $\gamma$ production by lymphocytes of O20/A mice is lower than by lymphocytes of OcB-9/Dem mice (both $H 2^{p z}$ ) stimulated in MLC by irradiated splenocytes of C57BL/10SnPh $\left(H 2^{b}\right)$ or BALB/ cHeA $\left(H 2^{d}\right)$ mice, or by ConA. IFN $\gamma$ production in MLCs of individual $(\mathrm{O} 20 \times \mathrm{OcB}-9) \mathrm{F}_{2}$ mice stimulated by irradiated
\end{abstract}

M. Lipoldová $(\bowtie) \cdot$ H. Havelková · J. Badalová .

J. Vojtíšková · M. Krulová · Y. Sohrabi

Department of Molecular and Cellular Immunology,

Institute of Molecular Genetics, Academy of Sciences

of the Czech Republic, Vídeňská 1083,

14220 Prague 4, Czech Republic

e-mail: lipoldova@img.cas.cz

Present Address:

J. Badalová

Institute of Care for Mother and Child,

Podolske Nabrezi 157, 14700 Prague 4, Czech Republic

L. Quan · P. Demant

Department of Molecular and Cellular Biology,

Roswell Park Cancer Institute, Buffalo, NY 14263, USA

A. P. Stassen

Department of Genetics and Cell Biology,

Maastricht University, Maastricht, The Netherlands
C57BL/10 splenocytes and genotyped for microsatellite markers revealed four IFN $\gamma$-controlling loci (Cypr4-Cypr7), each of which is closely linked with one of the four Lynf loci and with a cluster of susceptibility genes for different tumors. This suggests that inherited differences in certain lymphocyte responses may modify their propensity to infiltrate tumors and their capacity to affect tumor growth.

Keywords Genetic control of interferon $\gamma$ production . Gene mapping - Lymphocyte infiltration of tumors . Tumor susceptibility
Abbreviations
Cypr Cytokine production
Lynf Lymphocyte infiltration
MLC Mixed lymphocyte culture
MLR Mixed lymphocyte reaction
QTL Quantitative trait locus

\section{Introduction}

Interaction between the immune system and cancer is one of the most important determinants of cancer growth, progression, and metastasis. The interconnected processes of innate and adaptive immunity co-determine the development of cancer from the very beginning, when acute inflammation tends to suppress and chronic inflammation to promote carcinogenesis [1]. The interaction of adaptive immunity with cancer is less clear. It is a powerful agent in rejection of virally induced tumors [2], but its effects on spontaneous and carcinogen-induced tumors are still subject of discussion [3, 4]. Recently, however, in a 
number of human cancers it has been observed that presence of infiltrating $\mathrm{CD}^{+} \mathrm{T}$ lymphocytes is a positive prognostic factor [5], although in some studies their effect was mitigated by presence of T regulatory lymphocytes [6]. This indicated a positive role of $\mathrm{CD}^{+} \mathrm{T}$ lymphocytes in suppression of cancer. However, it is not known why infiltrating $\mathrm{T}$ lymphocytes are abundant in cancers of some patients but scarce in others. Although in the past decade, a large progress has been made in unravelling the sequence of molecular steps that participate in the passage of lymphocytes from blood circulation into tumor, and more than 60 different molecules (or closely related members of the same family) that facilitate and mediate lymphocyte traffic were identified [7], differences in structure or expression of these molecules were not yet correlated with individual propensity to tumor infiltration.

To the contrary, a new insight into the regulation of lymphocyte infiltration in tumors has been provided by the observations that the presence of infiltrating lymphocytes in mouse lung tumors is pronounced in some strains but virtually absent in others [8] and that this difference is controlled by four chromosomal loci designated LynflLynf4 (Lynf = Lymphocyte infiltration) that determine the presence of intra-tumoral infiltrating lymphocytes [9] in a cross between strains O20/A and OcB-9/Dem. Surprisingly, none of the four Lynf loci (Lynfl-chromosome 4; Lynf2-chromosome 8; Lynf3 and Lynf4-chromosome 6) encoded any of set of $>60$ molecules that were reported to participate in migration of lymphocytes into tumors. Therefore, other processes than direct molecular interactions of lymphocyte and surrounding tissue may be the primary determinants of individual's propensity to lymphocyte infiltration of tumors.

Our previous data showed that genetic polymorphisms of the intensity of nonspecific inflammation-related activity of immunocytes are linked with cancer susceptibility genes. We defined previously two loci, Marifl controlling production of IL-12, TNF $\alpha$ and iNOS, and Marif2 controlling production of TNF $\alpha$ and IL-12, by in vitro stimulated bone marrow-derived macrophages [10], and two loci, Cinda 3 and Cinda5, controlling in vitro proliferative response of lymphocytes to cytokines IL-2 and IL-4 [11]. Marif1 and Cinda 3 are linked to each other and Cinda 3 is closely linked to Lynfl as well as the mouse lung cancer susceptibility loci Sluc6/Sluc21 on chromosome 4. Marif2 and Cinda5 are linked to each other and to Lynf2 as well as to the mouse lung cancer susceptibility locus Sluc20 on chromosome 8 . This suggests a possible functional connection between activation of immunocytes and capacity of tumor infiltration.

In the present study, we analysed the genetic control of production of another cytokine, IFN $\gamma$, during in vitro reaction to major histocompatibility complex (MHC) alloantigens. The differences in the MHC antigens induce the strongest responses [12]. But genetic disparity in minor alloantigens also modifies the alloresponse. Earlier studies found that some strong MLC-stimulations $(M l s)$ antigens are coded by mouse $M t v$ (mammary tumor virus) [13]; later studies revealed a broad spectrum of additional minor human antigens [14]. Intensity of MLC-response to alloantigens is determined by two major factors-the genetic disparity between the responding and stimulating cells and the genetically defined intrinsic capacity of the responding cells to react to the stimulus [15-17].

Responder cells react to stimulator cells by proliferation and by cytokine production. We have studied the genetic basis of these two responses, using the recombinant congenic (RC) strains, which were developed for analysis of multigenically controlled biological processes [18]. A series of $\mathrm{RC}$ strains is derived from two parental inbred strains: a "background" strain and a "donor" strain. Each of these RC strains contains a different subset of about $12.5 \%$ of genes from the parental donor strain and the remaining approximately $87.5 \%$ of background strain genes. The BALB/ cHeA-c-STS/A (CcS) and O20/A-c-B10.O20/Dem (OcB) series of strains were used previously for analysis of alloantigen response. The strain distribution pattern of magnitude of proliferative response in MLR of individual RC strains to stimulator cells of four different strains was almost identical, indicating that differences in responsiveness, rather than the alloantigenic difference itself, determine the magnitude of the response, and that the responsiveness to different MHC alloantigens is largely controlled by the same genes $[19,20]$. We have mapped previously two of these responsiveness genes, Alan1 and Alan2 (Alloantigen response 1,2) located on chromosomes 17 and 4, respectively, that control differences in proliferative response to several alloantigens in $\mathrm{CcS}$ and $\mathrm{OcB} \mathrm{RC}$ strains [16, 17]. We have also shown that in the individual RCS the levels of proliferation and IL-2 production in MLR are not correlated, and therefore these two responses are under a different genetic control [19].

In the present work we defined four loci, Cypr4-Cypr7 $($ Cypr $=$ Cytokine production $)$, that control IFN $\gamma$ production by responder cells in MLR. IFN $\gamma$ plays important role in immunity against infection, and it has been associated with a number of autoinflammatory and autoimmune diseases (reviewed in [21]). IFN $\gamma$ has also multiple and diverse essential functions in immune response to cancer [22-25]. For that reason, genetics of capacity of IFN $\gamma$ production may be important for a variety of biological reactions. Here we show that control of IFN $\gamma$ production is genetically linked to and possibly responsible for the control of intensity of lymphocyte infiltration in tumors and control of tumor growth and progression. 


\section{Materials and methods}

Mice

Males and females of strains O20/A (abbrev. O20), OcB-9/ Dem (abbrev. OcB-9) (both strains have the MHC haplotype $H 2^{p z}$ ) and $\mathrm{F}_{2}$ hybrids between $\mathrm{O} 20$ and OcB-9 came from P. Demant's breeding colony. The haplotype $H 2^{p z}$ is described in [26]. The genetic composition of strain OcB-9 has been described in detail by Stassen and co-workers [27]. When used for these experiments strain OcB-9 passed more than 31 generations of brother-sister mating and was highly homozygous. C57BL/10SnPh (abbrev. B10) $\left(H 2^{b}\right)$ mice were from the Institute of Molecular Genetics (Prague). As the strains O20 and OcB-9 are MHC identical, all mixed lymphocyte reactions tested in this paper involved the same MHC incompatibility $\left(H 2^{p z}-H 2^{b}\right)$.

Mixed lymphocyte culture

Spleen cells of O20, OcB-9, and of individual $\mathrm{F}_{2}$ hybrid mice $\left(6 \times 10^{5}\right.$ cells per well) were mixed with $8 \times 10^{5}$ irradiated (3000 R) C57BL/10 stimulator cells in $800 \mu \mathrm{l}$ in 24-well tissue culture plates in complete RPMI 1640 medium, respectively (Nunc, Roskilde, Denmark) [28]. Supernatants were removed after $96 \mathrm{~h}$ incubation period and stored at $-70^{\circ} \mathrm{C}$ before use. Each day in a separate experiment $20 \mathrm{~F}_{2}$ mice and appropriate controls (O20 and OcB-9 mice) were tested. In the experiments, comparing IFN $\gamma$, IL-2, and IL-4 production by stimulated lymphocytes of strains $\mathrm{O} 20$ and OcB-9, supernatants were removed also 48 and $72 \mathrm{~h}$ after stimulation.

\section{Concanavalin A-stimulated cultures}

Spleen cells $\left(4 \times 10^{5}\right.$ cells per well $)$ were incubated in $800 \mu \mathrm{l}$ in 24-well tissue culture plates in complete RPMI 1640 medium with $2.5 \mu \mathrm{g} / \mathrm{ml}$ ConA. Supernatants were collected after 24,48 , or $72 \mathrm{~h}$ of incubation and assayed for IFN $\gamma$ presence.

Estimation of cytokine levels

Supernatants from MLR cultures were assayed for IFN $\gamma$, IL-2, and IL-4 presence using the primary and secondary mAbs (R46A2, XMG1.2; JES6-1A11, JES6-5H4; 11B11, BVD6-24G2) and standards (mIFN $\gamma, \mathrm{mIL}-2$, and mIL-4) from BD Bioscience, San Jose, CA. Similarly, supernatants from ConA stimulated cultures were assayed for IFN $\gamma$. The ELISA was performed using the conditions recommended by $\mathrm{BD}$ Bioscience. In brief, a 96-well flatbottom plate (Costar, Cambridge, MA) was coated with primary $\mathrm{mAb}$ at a concentration of $1 \mu \mathrm{g} / \mathrm{ml}$ in $0.1 \mathrm{M}$ $\mathrm{NaHCO}_{3} \mathrm{pH} 8.2$ and incubated overnight at $4^{\circ} \mathrm{C}$. The plates were washed with PBS-Tween (Costar, Corning, NY) and incubated for $2 \mathrm{~h}$ with $200 \mu \mathrm{l}$ of PBS $8 \%$ BSA. After washing, aliquots of supernatants were added to duplicate wells and incubated overnight at $4^{\circ} \mathrm{C}$. Plates were washed again and biotin-labeled secondary mAb was added for $45 \mathrm{~min}$. Plates were washed, followed by addition of horseradish peroxidase streptavidin (Vector Laboratories, Burlingame, CA). 2,2'-azino-bis(3-ethylbenzthiazoline-6-sulfonic acid) (Sigma-Aldrich, St. Louis, MO) and peroxide were used as chromogen. Color reaction was stopped by sodium dodecyl sulfate (SDS) in $\mathrm{N}, \mathrm{N}$ dimethylformamide and plates were read at OD $405 \mathrm{~nm}$ and the IFN $\gamma$ levels were estimated by the ELISA reader Tecan and the curve fitter program KIM-E (Schoeller Pharma, Prague, Czech Republic) using least square nonlinear regression analysis. Sensitivity of detection of IFN $\gamma$, IL-2, and IL-4 levels in supernatants was 32, 4, and $15 \mathrm{pg} / \mathrm{ml}$, respectively.

\section{Genotyping of microsatellites by PCR}

DNA was isolated from tails using a standard proteinase procedure. The strain OcB-9 differs from $\mathrm{O} 20$ by carrying B10.O20-derived segments at 10 chromosomes [27]. These differential segments were typed in the $\mathrm{F}_{2}$ hybrid mice using 15 microsatellite markers: D2Mit7, D2Mit56; D4Mit54; D6Mit31, D6Mit52; D7Mit12, D7Nds2; D8Mit3, D8Mit65; D10Mit12; D11Mit15; D16Mit130; D18Mit17; D19Mit3, D19Mit63. These markers were selected because they cover optimally the chromosomal segments at which the OcB-9 strain has genetic material from the B10.O20 strain. They carry different alleles in the two parental strains, the $\mathrm{O} 20$ allele (designated $o$ ), and the B10.O20 allele (designated $b$ ). PCR genotyping was performed as described [29]. Briefly, amplification was performed with a MJ Research Thermal Cycler PTC 100 Model 96 (MJ Research, Watertown, MA) in a volume of $10 \mu \mathrm{l}$ with $20 \mathrm{ng}$ DNA, $0.23 \mu \mathrm{M}$ of forward primer $\left[\gamma_{-}^{32} \mathrm{P}\right] \mathrm{ATP}$ end-labeled with T4 polynucleotide kinase (New England Biolabs, Schwalbach, Germany), $0.23 \mu \mathrm{M}$ of reverse primer, $200 \mu \mathrm{M}$ of each dNTP and $0.04 \mathrm{u}$ Taq polymerase (GIBCO, Grand Island, NY) in a 96-well Ubottom microtiter plate (FALCON, Oxford, UK) with 1 cycle of $3 \mathrm{~min}$ at $94^{\circ} \mathrm{C}$ and 30 cycles of $30 \mathrm{~s}$ at $94^{\circ} \mathrm{C}, 1 \mathrm{~min}$ at $55^{\circ} \mathrm{C}$ and $1 \mathrm{~min}$ at $72^{\circ} \mathrm{C}$ and 1 cycle of $1 \mathrm{~min}$ at $55^{\circ} \mathrm{C}, 3 \mathrm{~min}$ at $72^{\circ} \mathrm{C}$, and $1 \mathrm{~min}$ at $23^{\circ} \mathrm{C}$. Each PCR product was mixed with $30 \mu \mathrm{l}$ of loading buffer and electrophoresed in 6\% acrylamide gels for 2-2.5 h at $50 \mathrm{~W}$. Gels were wrapped in Saran Wrap (Dow Chemicals Co., Midland, MI) and exposed to X-ray film X-OMAT AR (Kodak, Weesp, The Netherlands) for $1.5-24 \mathrm{~h}$ at $-70^{\circ} \mathrm{C}$. 
Statistical analysis

The role of genetic factors in IFN $\gamma$ production in MLR response was examined by analysis of variance [ANOVA, PROC GLM statement of the SAS 8.2 for Windows (SAS Institute, Cary, NC)]. The effect of each marker, sex, and experiment on IFN $\gamma$ level in supernatants was tested. Each individual marker and its interactions with other markers and sex or experiment were subjected to ANOVA. A backward elimination procedure [30] was followed wherein the interaction of marker (or interaction) bearing the highest $P$ value (if $P>0.05$ ) was eliminated first. The markers and interactions with $P$ value smaller than 0.05 were pooled for the next round of ANOVA. The backward elimination procedure was repeated till the final set of significant markers and interactions was obtained. The $P$ values $\left(P c=\alpha_{\mathrm{T}}\right)$ were corrected according to Lander and Kruglyak [31] using the formula:

$\alpha_{T^{*}} \approx[C+2 \rho G h(T)] \alpha_{T}$

with $G=2 \mathrm{M}$ (the length of the segregating part of the genome: $12.5 \%$ of $16 \mathrm{M}$ ); $C=10$ (number of chromosomes segregating in this cross); $\rho=1.5$ for $\mathrm{F}_{2}$ hybrids; and $h(T)=$ the observed statistics ( $F$ ratio).

IFN $\gamma$, IL-2, and IL- 4 production in MLR by cells of responder strains O20 and OcB-9 was compared by MannWhitney $U$ test (STATISTICA for Windows 5.0, StatSoft, Inc., Tulsa, OK).

\section{Results}

Strain differences in proliferation and production of cytokines after stimulation with alloantigen or ConA

The proliferation of lymphocytes of the strain OcB-9 in MLC is higher than that of the MHC-identical strain O20 (both $H 2^{p z}$ ) after stimulation with lymphocytes of strains with $\mathrm{C} 57 \mathrm{BL} / 10\left(H 2^{b}\right), \mathrm{BALB} / \mathrm{cHeA}\left(H 2^{d}\right)$, and CBA $\left(H 2^{k}\right)$ that carry unrelated MHC haplotypes (Fig. 1 and Ref. 17). This indicates that strain OcB-9 has a higher propensity to respond to a variety of alloantigens than $\mathrm{O} 20$. The production of IFN $\gamma$ in MLC is also significantly higher by OcB-9 than by O20 responder cells when stimulated by C57BL/10 $\left(H 2^{b}\right)$ cells (Fig. 2a) and $\mathrm{BALB} / \mathrm{c}\left(H 2^{d}\right)$ cells, but it is low in both with weaker stimulators DBA $\left(H 2^{q}\right)$ and CBA $\left(H 2^{k}\right)$ (Fig. 2b). OcB-9 lymphocytes are also better producers of IFN $\gamma$ than $\mathrm{O} 20$ lymphocytes after stimulation with ConA (Fig. 3). In MLC with C57BL/10 stimulator cells, the production of IL-2 (Fig. 4a) but not of IL-4 (Fig. 4b) is higher by OcB-9 than O20 responder cells.

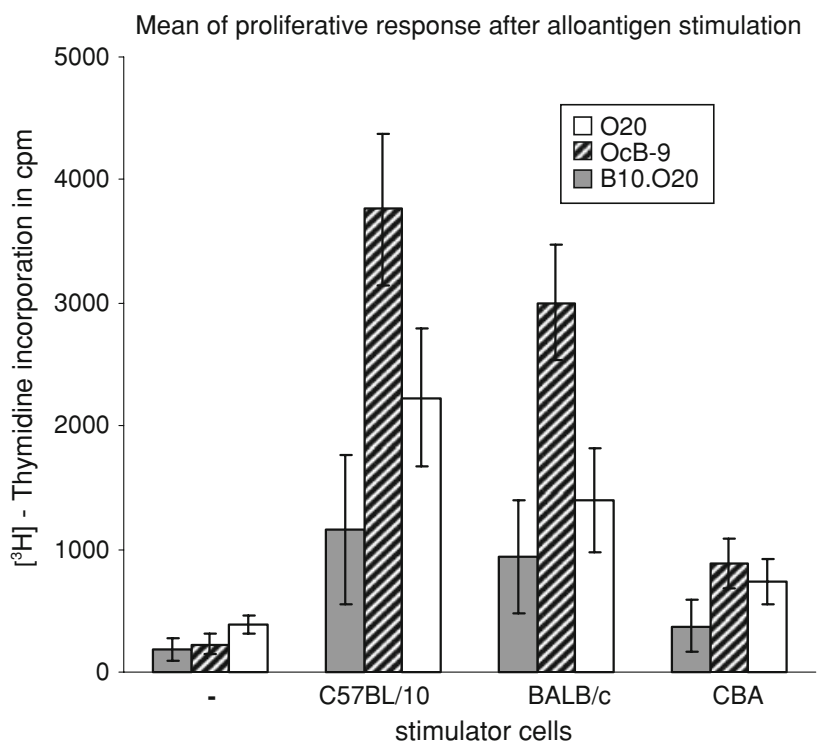

Fig. 1 The MLC reactivity of O20, B10.O20, and OcB-9 strains. Proliferative response of spleen cells in RPMI medium only and stimulated by C57BL/10Sn $\left(H 2^{b}\right)(\mathrm{B} 10), \mathrm{BALB} / \mathrm{c}\left(H 2^{d}\right)$, and $\mathrm{CBA} / \mathrm{Ph}$ $\left(H 2^{k}\right)$ alloantigens. Spleen cells $\left(1.5 \times 10^{5}\right.$ cells per well $)$ were mixed with $2 \times 10^{5}$ irradiated (3000 R) B10, BALB/c or CBA/Ph stimulator cells in $200 \mu \mathrm{l}$ in 96-well tissue culture plates. [3H]-thymidine $(0.5 \mu \mathrm{Ci} /$ well $)$ was added into the cultures for the last $6 \mathrm{~h}$ of the $96-\mathrm{h}$ incubation period as described previously [17]. The data show the mean \pm SE from three independent experiments. Reproduced with the kind permission from Ref. [17]

Detection of loci that control IFN $\gamma$ level in MLC

Supernatants of the spleen cells of the strain OcB-9 contain higher concentration of IFN $\gamma 96 \mathrm{~h}$ after stimulation with C57BL/10 cells than supernatants of spleen cells of strain O20 ( $P<0.014)$ (Fig. 2a). We examined production of IFN $\gamma$ in $240 \mathrm{~F}_{2}$ hybrids between the strains $\mathrm{O} 20$ and OcB-9. The strains O20 and OcB-9 differ in their genetic material at 10 chromosomes [27]. These differential segments were typed in the $\mathrm{F}_{2}$ hybrids mice using 15 microsatellite markers listed above.

Statistical analysis revealed four genetic loci that influence level of IFN $\gamma$ in supernatants of $(\mathrm{O} 20 \mathrm{xOcB}-9) \mathrm{F}_{2}$ splenocytes stimulated by irradiated C57BL/10 cells. Two of these loci have individual effects, but the other two operate in mutual nonadditive interaction. Two loci, Cypr4 (Cytokine production 4) linked to D6Mit31 (corrected $P$ value $<0.00717$ ) and Cypr5 linked to D6Mit52 (corrected $P$ value $<0.000257$ ) have effect on IFN $\gamma$ production after alloantigen stimulation that is not influenced by interaction with other genes (main effects) (Table 1). These loci have an opposite effect on the studied trait. The homozygosity for the O20 allele of Cypr4 (oo) determines about twofold higher level of IFN $\gamma$ than the homozygosity of the B10.O20 allele $(b b)$, whereas homozygosity for the $\mathrm{O} 20$ allele of 
a Mean of IFN $\gamma$ production after alloantigen stimulation by $\mathrm{C} 57 \mathrm{BL} / 10$ splenocytes

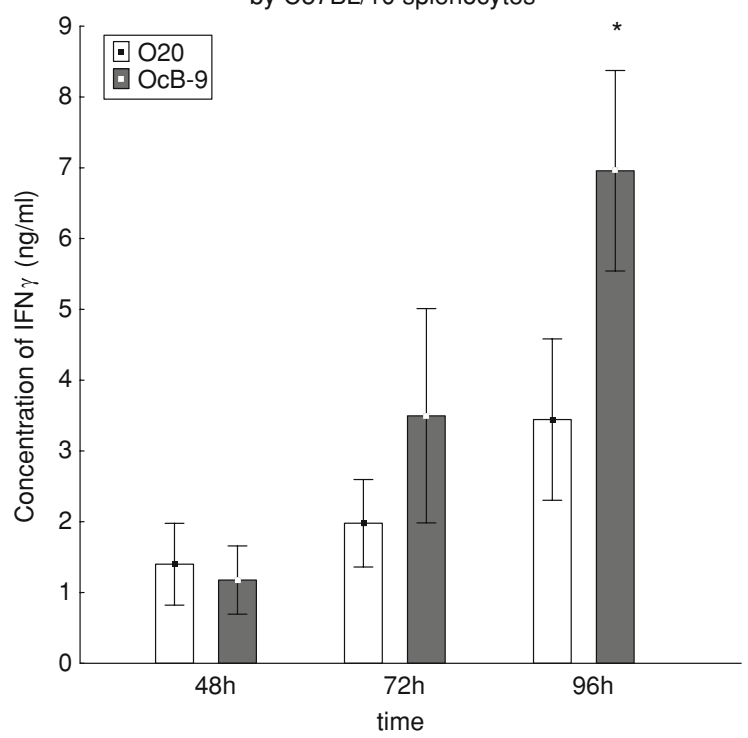

b Mean of IFN $\gamma$ production after alloantigen stimulation

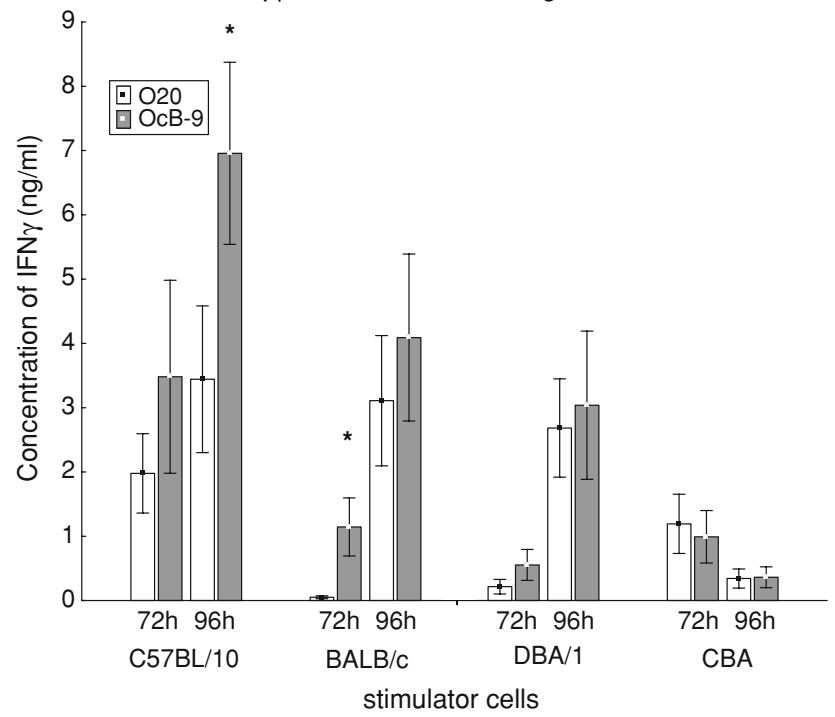

Fig. 2 a Comparison of concentration of IFN $\gamma$ in supernatants of the spleen cells of the strains OcB-9 and O20 after alloantigen stimulation. Spleen cells $\left(6 \times 10^{5}\right.$ cells per well) were mixed with $8 \times 10^{5}$ irradiated (3000 R) C57BL/10 stimulator cells in $800 \mu \mathrm{l}$ in 24-well tissue culture plates. Cell supernatants were analyzed 48, 72, and $96 \mathrm{~h}$ after stimulation. Data summarize the result of 13 independent experiments. Both female and male mice were used in our analysis, but no influence of sex on strain difference was observed. The columns show the means $\pm \mathrm{SE}$ of IFN $\gamma$ concentration in $\mathrm{ng} / \mathrm{ml}$. Filled square: OcB-9, unfilled square: O20. b Comparison of concentration of IFN $\gamma$ in supernatants of the spleen cells of the strains OcB-9 and O20 after stimulation by C57BL/10Sn $\left(H 2^{b}\right)$, $\mathrm{BALB} / \mathrm{c}\left(H 2^{d}\right), \mathrm{CBA}\left(H 2^{k}\right)$, and DBA/1 $\left(H 2^{q}\right)$ alloantigens. Spleen cells $\left(6 \times 10^{5}\right.$ cells per well $)$ were mixed with $8 \times 10^{5}$ irradiated (3000 R) C57BL/10Sn, BALB/c, CBA, or DBA/1 stimulator cells in $800 \mu \mathrm{l}$ in 24-well tissue culture plates. Cell supernatants were analysed 72 and $96 \mathrm{~h}$ after stimulation. Data summarize the result of 13 independent experiments

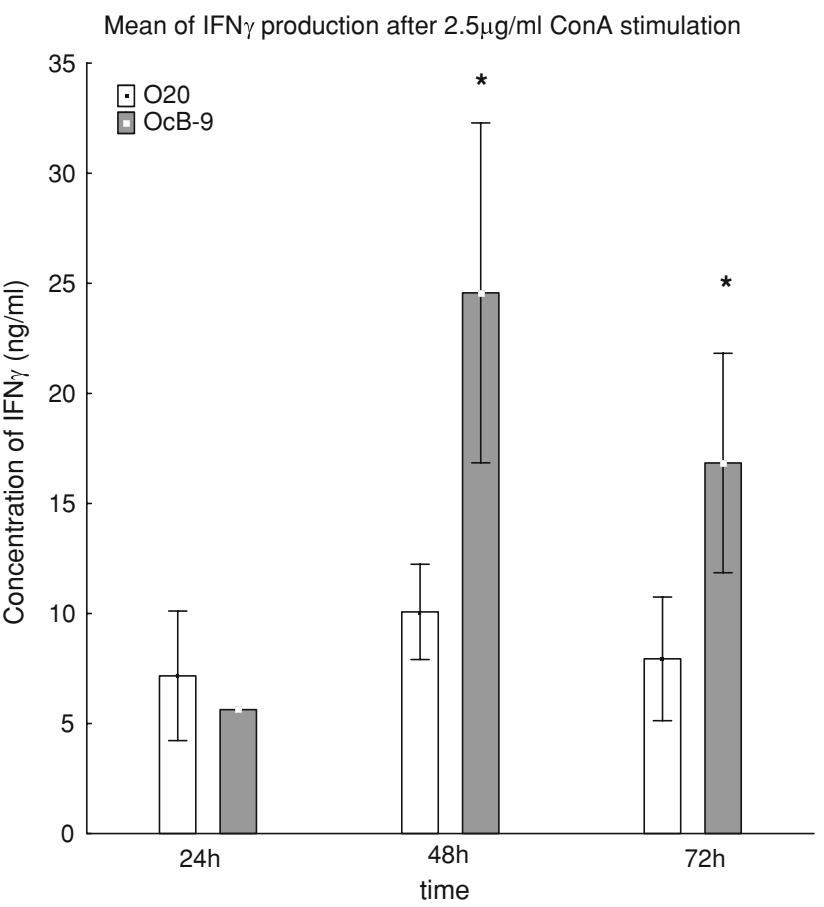

Fig. 3 Comparison of concentration of IFN $\gamma$ in supernatants of the spleen cells of the strains OcB-9 and O20 after stimulation with $2.5 \mu \mathrm{g} / \mathrm{ml}$ ConA. To test IFN $\gamma$ concentration, $800 \mu \mathrm{l}$ of spleen cells $\left(4 \times 10^{5}\right.$ cells per well $)$ were incubated in 24 -well tissue culture plates in complete RPMI 1640 medium with $2.5 \mu \mathrm{g} / \mathrm{ml}$ ConA. After 24,48 , or $72 \mathrm{~h}$ of incubation supernatants were collected and assayed for IFN $\gamma$ presence. The columns show the means \pm SE of IFN $\gamma$ concentration in $\mathrm{ng} / \mathrm{ml}$. Data summarize the result of four independent experiments. Square: OcB-9, unfilled square: O20

Cypr5 is associated with about two-and-half fold decrease level of this cytokine than the homozygosity of the B10.O20 allele. Influence of the experimental group was evident $\left(P<1.75 \times 10^{-24}\right)$, but no significant interaction between experimental group and marker was observed.

Cypr6 influences IFN $\gamma$ level in interaction with Cypr 7 (corrected $P<0.00111$ ). $\quad F_{2}$ mice with homozygous B10.O20 (bb) alleles at Cypr6 and O20 (oo) alleles at Cypr7 or homozygous for B10.O20 allele at $\mathrm{Cypr} 7$ and homozygous for $\mathrm{O} 20$ alleles in Cypr6 produce approximately twice higher IFN $\gamma$ level in supernatants in alloantigen-stimulated spleen cells in comparison with other combinations of Cypr6 and Cypr7 $\mathrm{O} 20$ and B10.O20 alleles (Table 2). The levels of IFN $\gamma$ seem to be negatively correlated with the intensity of lymphocyte infiltration, both in the strains and in comparable genotypes. The production of IFN $\gamma$ is higher in the strain OcB-9 than O20, while in $\mathrm{O} 20$ mice the numbers of intratumoral lymphocytes are higher than in OcB-9 [8]. A similar negative correlation is seen also at locus level: IFN $\gamma$ levels at the three Cypr4 genotypes are negatively correlated with lymphocyte infiltration scores at the corresponding 

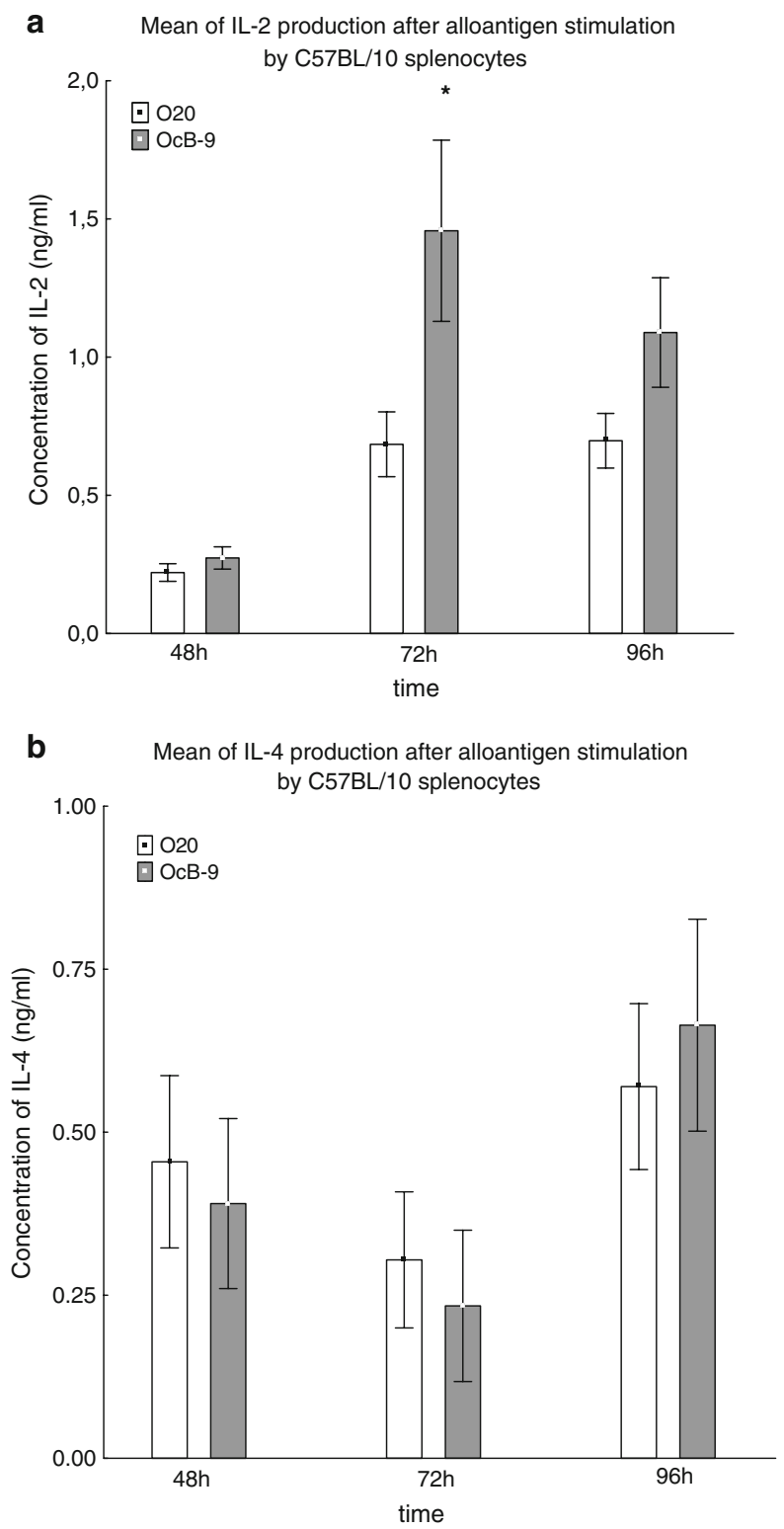

Fig. 4 a Comparison of concentration of IL-2 in supernatants of the spleen cells of the strains OcB-9 and O20 after alloantigen stimulation. Spleen cells $\left(6 \times 10^{5}\right.$ cells per well $)$ were mixed with $8 \times 10^{5}$ irradiated (3000 R) C57BL/10 stimulator cells in $800 \mu \mathrm{l}$ in 24-well tissue culture plates. Cell supernatants were analysed 48, 72, and $96 \mathrm{~h}$ after stimulation. Data summarize the result of 13 independent experiments. Both female and male mice were used in our analysis, but no influence of sex on strain difference was observed. The columns show the means \pm SE of IL-2 concentration in $\mathrm{ng} / \mathrm{ml}$. Filled square: OcB-9, unfilled square: O20. b Comparison of concentration of IL-4 in supernatants of the spleen cells of the strains OcB-9 and O20 after alloantigen stimulation. Spleen cells $\left(6 \times 10^{5}\right.$ cells per well) were mixed with $8 \times 10^{5}$ irradiated $(3000 \mathrm{R})$ C57BL/10 stimulator cells in $800 \mu \mathrm{l}$ in 24-well tissue culture plates. Cell supernatants were analysed 48,72 , and $96 \mathrm{~h}$ after stimulation. Data summarize the result of 13 independent experiments. Both female and male mice were used in our analysis, but no influence of sex on strain difference was observed. The columns show the means \pm SE of IL-4 concentration in $\mathrm{ng} / \mathrm{ml}$. Filled square: OcB-9, unfilled square: $\mathrm{O} 20$ genotypes [9] of the co-localizing Lynf4 locus: oo: IFN $\gamma$ $7.74 \mathrm{ng} / \mathrm{ml}$, infiltration score (IS) - $0.04 ; o b:$ IFN $\gamma-$ $5.77 \mathrm{ng} / \mathrm{ml}$, (IS)—0.39; $b b:$ IFN $\gamma-3.78 \mathrm{ng} / \mathrm{ml}$, (IS) -0.34 . Allelic correlations within the other Cypr-Lynf could not be assessed, because these loci were defined by inter-locus interactions.

\section{Discussion}

In the present study, we demonstrate genetic linkage between in vitro production of IFN $\gamma$ and in vivo lymphocyte infiltration of tumors. Previously, we have shown that responder's genotype strongly influences various in vitro responses of lymphocytes to stimulation by allogeneic cells [16, 17], anti-CD3 antibodies [28], mitogens [32], and cytokines $[11,28]$. Importantly, in MLC these differences in response were obvious in spite of identical MHC incompatibility. We have shown that these differences are controlled by several loci with quantitative additive effects, and that different components of a response, for example proliferation or production of different cytokines, are controlled by different genes. We observed that two genetic loci that control activation of macrophages [10] and lymphocytes [11] co-localize with the genes that control susceptibility to lung tumors. This suggested that the loci regulating activity of lymphocytes and macrophages in vitro could have also in vivo effect on tumor growth. The genetic analysis of production of IFN $\gamma$ by responder lymphocytes in allogeneic mixed lymphocyte cultures demonstrated four genetic loci with significant influence. We analyzed the difference in the phenotype of interferon production between the strain $\mathrm{O} 20$ and the $\mathrm{RC}$ strain $\mathrm{OcB}$ 9 that is in about $87.5 \%$ genes identical to $\mathrm{O} 20$, but received a random subset of about $12.5 \%$ of genes from the strain B10.O20 [18, 27]. The genetic material obtained from B10.O20 is almost entirely contained in several contiguous chromosomal segments, mostly $10-20 \mathrm{cM}$ long. They were described previously [27, 33] and are covered by 15 polymorphic microsatellite markers listed in "Materials and methods" section. Thus, any genetic differences between these two strains must be controlled by a gene or genes located in one of these B10.O20-derived segments [34]. It should be pointed out that the strains $\mathrm{O} 20$ and OcB-9 have identical MHC haplotype $\left(H 2^{p z}\right)$, so they respond to the same MHC incompatibility $\left(H_{2}{ }^{b}\right)$ and any difference in the response must be host-related. The stimulation by non-MHC alloantigens is not a likely cause of the observed differences in production of IFN $\gamma$ between O20 and OcB-9, because the two strains have the same genotype at the strong stimulatory locus Mtvl3 (Mls1) [27] and no other stimulators in MLC were described in the vicinity of the Cypr loci mapped here. 
Table 1 Effects of genotype at the loci Cypr4 and Cypr5 on the concentration of IFN $\gamma$ in supernatants of spleen cells of individual $\mathrm{F}_{2}$ hybrids between OcB-9 and O20 stimulated by irradiated B10 splenocytes

\begin{tabular}{llllll}
\hline Marker/locus & \multicolumn{2}{l}{ Genotype } & & $P$ value & Corrected $P$ \\
\cline { 2 - 5 } & $o o$ & $o b$ & $b b$ & 0.000100 \\
\hline D6Mit31 (Cypr4) & $7.74 \pm 0.60(n=64)$ & $5.77 \pm 0.47(n=105)$ & $3.78 \pm 0.69(n=63)$ & 0.00717 \\
D6Mit52 (Cypr5) & $3.66 \pm 0.74(n=55)$ & $5.09 \pm 0.47(n=121)$ & $9.43 \pm 0.66(n=63)$ & 0.00000296 & 0.000257 \\
\hline
\end{tabular}

The phenotypic values given for individual genotypes indicate mean and standard errors of the concentration of IFN $\gamma$ and (in brackets) the number of mice (for computations the measured values of IFN $\gamma$ in supernatants $(\mathrm{ng} / \mathrm{ml}$ ) were normalized by natural logarithm of (value +0.5$)$ to the power of 0.005$)$

Table 2 Effects of genotype at the loci Cypr6 and $C y p r 7$ on the concentration of IFN $\gamma$ in supernatants of spleen cells of $\mathrm{F}_{2}$ hybrids between OcB-9 and O20 stimulated by irradiated B10 splenocytes

\begin{tabular}{llrr}
\hline & \multicolumn{2}{l}{ D8Mit3 (Cypr7) } & \\
\cline { 2 - 4 } & oo & & \\
\hline D4Mit54 (Cypr6) & & & $b b$ \\
oo & $5.57 \pm 1.89(n=15)$ & $3.13 \pm 0.93(n=29)$ & $10.64 \pm 1.57(n=10)$ \\
$o b$ & $5.16 \pm 0.83(n=31)$ & $5.66 \pm 0.55(n=58)$ & $4.67 \pm 0.69(n=33)$ \\
$b b$ & $9.06 \pm 1.38(n=10)$ & $4.77 \pm 0.77(n=28)$ & $4.61 \pm 0.85(n=11)$ \\
\hline
\end{tabular}

The phenotypic values given for individual genotypes indicate mean and standard errors of the concentration of IFN $\gamma$ and (in brackets) the number of mice. (B10.O20 allele $b$, O20 allele $o$ ), $P$ value $=$ nominal $P$ value, corrected $P=P$ value corrected for total genome screen)

$P$ value $=0.000189$, corrected $P$ value $=0.00111$

However, the higher production of IFN $\gamma$ by OcB-9 cells is not likely a mere consequence of a higher proliferative response. We measured proliferation in parallel MLCs of individual $\mathrm{F}_{2}$ hybrid animals that were tested for IFN $\gamma$ production. We found in that population only one locus controlling the proliferation, Alan2 [17]. It is linked to a marker that is different from but relatively close $(6 \mathrm{cM})$ to the marker identifying Cypr6, so the identity of the two loci is neither indicated nor ruled out. The other three loci (Cypr4, 5, and 7) were not linked to proliferative activity in MLR. This prevailing genetic independence of proliferation and IFN $\gamma$ production in MLC is similar to the extensively documented distinct genetic control of lymphocyte proliferation and IL-2 production in MLC [19].

An unexpected feature of our data is the complete colocalization of the four newly detected loci Cypr controlling production of IFN $\gamma$ in mixed lymphocyte culture with the four Lynf loci that control infiltration of lymphocytes into tumors: Cypr4-Lynf4; Cypr5-Lynf3; Cypr6-Lynf1; Cypr7-Lynf2. This general Cypr-Lynf co-localization contrasts sharply with a complete lack of co-localization of Lynf loci with any genes encoding the more than 60 molecules that were either reported to participate in traffic of lymphocytes from the circulation to tumors or belong to the same family [9]. This suggests that, contrary to the prevailing emphasis in the literature, the principal control of capacity of lymphocytes to infiltrate tumors might reside in the regulation of the processes of lymphocyte activation.

In addition, the four Cypr loci described here co-localize with or are linked to a number of loci that control susceptibility to or patterns of progression of a variety of tumors that were independently described by different groups (Table 3). Cypr4 is linked to four such loci, Mmom1, Ots1, Pas1c, Skts11, Cypr5 to one locus, Ltsd8, Cypr6 to 15 loci (10 of them within $5 \mathrm{cM}$ ) Gct1, Ltsd4, Naad5, Nbl1, Pcts, Sluc6, Sluc21, Ssic1, Stmn1, Tlsr3, and Cypr7 to 7 loci Dlc1, Ltq, Ltsd3, Mfhas1, Sluc20, Scc8, Poats1.

IFN $\gamma$ has an important role in host defenses, in both innate and acquired immunity. IFN $\gamma$ is produced by many different cell types, such as by T cells, NK cells, NKT cells [35] upon their stimulation by antigens or mitogens. Macrophages and other accessory cells, such as dendritic cells, besides having a boosting effect on IFN $\gamma$ production by resting $\mathrm{T}$ cells [36] can themselves also produce large amounts of IFN $\gamma$ [37]. The interaction of $\mathrm{T}$ cells with antigen-presenting cells results in the production of IL-1, which then activates the $\mathrm{T}$ cells to produce IL-2, which promotes the IFN $\gamma$ production [38]. All IFN $\gamma$ inducers activate $\mathrm{T}$ cells either in a polyclonal (mitogen or antibodies) or a clonally restricted (antigen-specific) manner.

IFN $\gamma$ (class II interferon) mediates broad immune responses to pathogens. It binds to IFNGR1/IFNGR2 
Table 3 Co-localization of the four Cypr loci with cancer susceptibility loci/genes

\begin{tabular}{|c|c|c|c|c|c|}
\hline $\begin{array}{l}\text { Locus with } \\
\text { border markers }\end{array}$ & Marker & $\mathrm{cM}$ & Locus/Gene & $\mathrm{cM}$ & Reference \\
\hline $\mathrm{O} 20(o)$ & D6Mit29 & 36.50 & Lynf4 (Lymphocyte infiltration 4) & 35.15 & [9] \\
\hline $\mathrm{B} 10(b)$ & D6Mit31 & 38.50 & Skts11 (skin tumor susceptibility 11 ) & 36.50 & {$[42]$} \\
\hline Cypr4 (b) & D6Mit31 & 38.50 & Pas1c (pulmonary adenoma susceptibility 1c) & 37.00 & [43] \\
\hline $\mathrm{B} 10(b)$ & D6Mit327 & 46.50 & Mmom3 (mammary modifier of Min3) & 38.50 & {$[44]$} \\
\hline $\mathrm{O} 20(o)$ & D6Mit10 & 48.70 & Ots1 (ovarian teratoma susceptibility 1 ) & 40.00 & {$[45]$} \\
\hline $\mathrm{O} 20(o)$ & D6Mit334 & 60.75 & Ltsd8 (lung tumor shape-determining 8) & 61.20 & [46] \\
\hline $\mathrm{B} 10(b)$ & D6Mit256 & 60.95 & Lynf3 (Lymphocyte infiltration 3) & 61.20 & [9] \\
\hline Cypr5 (b) & D6Mit52 & 61.40 & & & \\
\hline $\mathrm{B} 10(b)$ & D6Mit370 & 62.67 & & & \\
\hline $\mathrm{O} 20(o)$ & D6Mit13 & 63.60 & & & \\
\hline $\mathrm{O} 20(o)$ & D4Mit37 & 56.50 & Lci (liver cell immortalization) & 57.50 & {$[47]$} \\
\hline \multirow[t]{5}{*}{$\mathrm{B} 10(b)$} & D4Mit11 & 57.40 & Naad4 (Neu associated allelic deletion 4) & 57.40 & [48] \\
\hline & & & Ril3 (radiation-induced leukemia sensitivity 3) & 60.00 & [49] \\
\hline & & & Sluc 21 (susceptibility to lung cancer 21 ) & 63.00 & {$[30]$} \\
\hline & & & Tlsr3 (thymic lymphoma suppressor region 3) & 63.10 & {$[50]$} \\
\hline & & & Stmn1 (stathmin 1) & 65.70 & {$[51]$} \\
\hline \multirow[t]{8}{*}{ Cypr6 (b) } & D4Mit54 & 66.00 & Naad5 (Neu associated allelic deletion 5) & 66.00 & {$[52]$} \\
\hline & & & Ltsd4 (lung tumor shape-determining 4) & 67.00 & [46] \\
\hline & & & Sluc6 (susceptibility to lung cancer 6) & 67.00 & {$[53]$} \\
\hline & & & Lynf1 (Lymphocyte infiltration 1) & 67.00 & [9] \\
\hline & & & Ssic1 (susceptibility to small intestinal cancer 1) & 67.00 & {$[54]$} \\
\hline & & & Nbll (neuroblastoma, suppression of tumorigenicity 1 ) & 70.00 & {$[55]$} \\
\hline & & & Pcts (plasmacytoma susceptibility) & 70.00 & {$[56]$} \\
\hline & & & Gct1 (granulosa cell tumorigenesis 1) & 71.00 & {$[57]$} \\
\hline $\mathrm{B} 10(b)$ & D4Mit342 & 77.50 & Pctr2 (plasmacytoma resistance 2) & 73.50 & {$[58]$} \\
\hline $\mathrm{O} 20(o)$ & D4Mit59 & 78.90 & Tlsr2 (thymic lymphoma suppressor region 2) & 76.60 & {$[50]$} \\
\hline \multirow[t]{3}{*}{$\mathrm{O} 20(o)$} & Markers start at $1 \mathrm{cM}$ & & Scc8 (colon tumor susceptibility 8 ) & 4.0 & {$[59]$} \\
\hline & & & Poats1 (post-ovarectomy adrenal tumor susceptibility 1 ) & 8.0 & {$[60]$} \\
\hline & & & Ltsd3 (lung tumor shape-determining 3) & 10.00 & {$[46]$} \\
\hline $\mathrm{B} 10(b)$ & D8Mit155 & 1.00 & Sluc20 (susceptibility to lung cancer 20 ) & 10.00 & {$[30]$} \\
\hline \multirow[t]{2}{*}{ Cypr7 (b) } & D8Mit3 & 10.00 & Lynf2 (lymphocyte infiltration 2) & 10.00 & [9] \\
\hline & & & Mfhas 1 (malignant fibrous histiocytoma amplified sequence 1) & 20.00 & {$[61]$} \\
\hline $\mathrm{B} 10(b)$ & D8Mit98 & 28.00 & Dlc1 (deleted in liver cancer 1$)$ & 21.00 & {$[62]$} \\
\hline $\mathrm{O} 20(\mathrm{o})$ & D8Mit66 & 28.00 & Ltq (lung tumor QTL) & 30.00 & [63] \\
\hline
\end{tabular}

receptor complex and uses JAK1/JAK2/STAT1 signaling pathway (reviewed in [39]). IFN $\gamma$ modulates the expression of major histocompatibility antigens on many different accessory cells, and thus stimulates interaction of these cells with T cells. Enhanced expression of class II antigens after IFN $\gamma$ treatment also takes place on cells of $\mathrm{T}$ and $\mathrm{B}$ lineage [40]. In the nonlymphoid organs, increased MHC antigens are found mainly on capillary endothelial cells, on renal tubular cells and on bronchiolar epithelial cells.

The role IFN $\gamma$ in suppression of tumor growth has been known for long time and the extensive literature cannot be reviewed here. Availability of genetically modified mice allowed to demonstrate also the role of IFN $\gamma$ in various aspects of anti-tumor immune responses [22-24, 41]. In some tests, it has been shown that this role may differ in different mouse strains [22]. The present data show not only a linkage between the four Cypr loci that control production of IFN $\gamma$, but also an apparently negative correlation between the IFN $\gamma$ levels and intensity of infiltration, not only in the tested strains, but also when comparing different alleles. However, the statistical significance of this relationship is not clear. Moreover, we are comparing results of a short-term assay (production of IFN $\gamma$ in MLR) and a condition of long duration (intensity of lymphocyte 
infiltration in tumors). Before the responsible Cypr-Lynf genes are identified, it is difficult to assess, which of the multiple effects of IFN $\gamma$ on lymphocytes, other inflammatory cells, vasculature, and tumor cells modifies the level of infiltration. Cypr-Lynf congenic strains, currently under production, will create possibilities for more detailed studies of function of these genes.

The data presented here may be a suitable model for analysis of the potent modifying effects of infiltrating lymphocytes in human cancer. Although the mechanisms of the suppressive effects of lymphocyte infiltration on growth of human cancers are not known, it is interesting that there is an extensive genetic association between the four Cypr-Lynf loci and more than 20 loci controlling susceptibility to and progression of a variety of mouse tumors (Table 3). Each of the four Cypr/Lynf loci is linked to a number of susceptibility loci to various tumors including lung, skin, ovary, liver, mammary gland, lymphomas, leukemia, plasmacytoma, and histiocytoma. This multiplicity of tumor types affected by these loci/genes is compatible with a genetic effect that is not organ specific but possibly systemic, like control of effective immunosurveillance.

In conclusion, our data provide a novel link between genetic polymorphisms of regulation of lymphocyte activation and genetic variation in immunoregulation of tumor growth. Analysis of the genes involved and their human homologues may contribute to the understanding of individual predisposition to a high or low anti-tumor activity of lymphocytes and thus improve the decisions about personalized selection of appropriate therapies.

Acknowledgments We thank Neelima Kakarlapudi for useful comments. This work was supported by Grant Agency of the Czech Academy of Sciences (Grant GA AV A500520606), by Ministry of Education of the Czech Republic (Project Grant LC 06009), Grant Agency of the Czech Republic (Grant 310/08/H077), and Academy of Sciences of the Czech Republic (Project Grant AVOZ50520514). P.D. and L.Q. are supported by Roswell Park Cancer Institute's Institutional Funds and by NIH-NCI Grant 1R01CA127162-01.

Open Access This article is distributed under the terms of the Creative Commons Attribution Noncommercial License which permits any noncommercial use, distribution, and reproduction in any medium, provided the original author(s) and source are credited.

\section{References}

1. de Visser KE, Eichten A, Coussens LM (2006) Paradoxical roles of the immune system during cancer development. Nat Rev Cancer 6:24-37

2. Klein G, Imreh S, Zabarovsky ER (2007) Why do we not all die of cancer at an early age? Adv Cancer Res 98:1-16

3. Smyth MJ, Dunn GP, Schreiber RD (2006) Cancer immunosurveillance and immunoediting: the roles of immunity in suppressing tumor development and shaping tumor immunogenicity. Adv Immunol 90:1-50
4. Willimsky G, Blankenstein $T$ (2007) The adaptive immune response to sporadic cancer. Immunol Rev 220:102-112

5. Galon J, Costes A, Sanchez-Cabo F, Kirilovsky A, Mlecnik B, Lagorce-Pages C, Tosolini M, Camus M, Berger A, Wind P, Zinzindohoue F, Bruneval P, Cugnenc PH, Trajanoski Z, Fridman WH, Pages F (2006) Type, density, and location of immune cells within human colorectal tumors predict clinical outcome. Science 313:1960-1964

6. Bui JD, Uppaluri R, Hsieh CS, Schreiber RD (2006) Comparative analysis of regulatory and effector $\mathrm{T}$ cells in progressively growing versus rejecting tumors of similar origins. Cancer Res 66:7301-7309

7. Chen Q, Wang WC, Evans SS (2003) Tumor microvasculature as a barrier to antitumor immunity. Cancer Immunol Immunother 52:670-679

8. Horlings H, Demant P (2005) Lung tumor location and lymphocyte infiltration in mice are genetically determined. Exp Lung Res 31:513-525

9. Kakarlapudi N, Vernooy JH, Quan L, Fijneman RJ, Demant P (2008) Control of lymphocyte infiltration of lung tumors in mice by host's genes: mapping of four Lynf (lymphocyte infiltration) loci. Cancer Immunol Immunother 57:217-225

10. Fijneman RJ, Vos M, Berkhof J, Demant P, Kraal G (2004) Genetic analysis of macrophage characteristics as a tool to identify tumor susceptibility genes: mapping of three macrophage-associated risk inflammatory factors, marif1, marif 2 , and marif3. Cancer Res 64:3458-3464

11. Lipoldová M, Havelková H, Badalová J, Demant P (2005) Novel loci controlling lymphocyte proliferative response to cytokines and their clustering with loci controlling autoimmune reactions, macrophage function and lung tumor susceptibility. Int J Cancer 114:394-399

12. Bodmer WF, Jones EA, Barnstable CJ, Bodmer JG (1978) Genetics HLA: the major human histocompatibility system. Proc R Soc Lond B Biol Sci 202:93-116

13. Huber BT (1992) Mls genes and self-superantigens. Trends Genet 8:399-402

14. Feng X, Hui KM, Younes HM, Brickner AG (2008) Targeting minor histocompatibility antigens in graft versus tumor or graft versus leukemia responses. Trends Immunol 29:624-632

15. Rychlikova M, Demant P, Ivanyi P (1973) The mixed lymphocyte reaction in $\mathrm{H}-2 \mathrm{~K}, \mathrm{H}-2 \mathrm{D}$, and non-H-2 incompatibility. Biomedicine 18:401-407

16. Holán V, Havelková $\mathrm{H}$, Krulová $\mathrm{M}$, Demant $\mathrm{P}$, Lipoldová $\mathrm{M}$ (2000) A novel alloreactivity-controlling locus, Alan1, mapped to mouse chromosome 17. Immunogenetics 51:755-757

17. Havelková H, Badalová J, Demant P, Lipoldová M (2000) A new type of genetic regulation of allogeneic response. A novel locus on mouse chromosome 4, Alan2 controls MLC reactivity to three different alloantigens: C57BL/10, BALB/c and CBA. Genes Immun 1:483-487

18. Demant P, Hart AA (1986) Recombinant congenic strains-a new tool for analyzing genetic traits determined by more than one gene. Immunogenetics 24:416-422

19. Holan V, Lipoldová M, Demant P (1996) Identical genetic control of MLC reactivity to different MHC incompatibilities, independent of production of and response to IL-2. Immunogenetics 44:27-35

20. Havelková H, Holan V, Karnik L, Lipoldová M (2006) Mouse model for analysis of non-MHC genes that influence allogeneic response: recombinant congenic strains of OcB/Dem series that carry identical $H 2$ locus. Central European Journal of Biology $1: 16-28$

21. Schoenborn JR, Wilson CB (2007) Regulation of interferongamma during innate and adaptive immune responses. Adv Immunol 96:41-101 
22. Street SE, Trapani JA, MacGregor D, Smyth MJ (2002) Suppression of lymphoma and epithelial malignancies effected by interferon gamma. J Exp Med 196:129-134

23. Enzler T, Gillessen S, Manis JP, Ferguson D, Fleming J, Alt FW, Mihm M, Dranoff G (2003) Deficiencies of GM-CSF and interferon gamma link inflammation and cancer. J Exp Med 197:1213-1219

24. Qin Z, Kim HJ, Hemme J, Blankenstein T (2002) Inhibition of methylcholanthrene-induced carcinogenesis by an interferon gamma receptor-dependent foreign body reaction. J Exp Med 195:1479-1490

25. Blankenstein $\mathrm{T}$ (2005) The role of tumor stroma in the interaction between tumor and immune system. Curr Opin Immunol 17: $180-186$

26. Klein J (1989) Immunologically important loci. In: Lyon M, Searle A (eds) Genetic variants and strains of the laboratory mouse. Oxford University Press, Oxford

27. Stassen AP, Groot PC, Eppig JT, Demant P (1996) Genetic composition of the recombinant congenic strains. Mamm Genome 7:55-58

28. Lipoldová M, Kosarová M, Zajicová A, Holán V, Hart AA, Krulová M, Demant P (1995) Separation of multiple genes controlling the T-cell proliferative response to IL-2 and anti-CD3 using recombinant congenic strains. Immunogenetics 41:301-311

29. Dietrich W, Katz H, Lincoln SE, Shin HS, Friedman J, Dracopoli NC, Lander ES (1992) A genetic map of the mouse suitable for typing intraspecific crosses. Genetics 131:423-447

30. Tripodis N, Hart AA, Fijneman RJ, Demant P (2001) Complexity of lung cancer modifiers: mapping of thirty genes and twenty-five interactions in half of the mouse genome. J Natl Cancer Inst 93:1484-1491

31. Lander E, Kruglyak L (1995) Genetic dissection of complex traits: guidelines for interpreting and reporting linkage results. Nat Genet 11:241-247

32. Kosarová M, Havelková H, Krulová M, Demant P, Lipoldová M (1999) The production of two Th2 cytokines, interleukin-4 and interleukin-10, is controlled independently by locus Cyprl and by loci Cypr2 and Cypr3, respectively. Immunogenetics 49:134-141

33. Groot PC, Moen CJ, Dietrich W, Stoye JP, Lander ES, Demant P (1992) The recombinant congenic strains for analysis of multigenic traits: genetic composition. FASEB J 6:2826-2835

34. Demant P (2003) Cancer susceptibility in the mouse: genetics, biology and implications for human cancer. Nat Rev Genet 4:721-734

35. Cui J, Shin T, Kawano T, Sato H, Kondo E, Toura I, Kaneko Y, Koseki H, Kanno M, Taniguchi M (1997) Requirement for Valpha14 NKT cells in IL-12-mediated rejection of tumors. Science 278:1623-1626

36. Blanchard DK, Djeu JY, Klein TW, Friedman H, Stewart WE 2nd (1986) Interferon-gamma induction by lipopolysaccharide: dependence on interleukin 2 and macrophages. J Immunol 136:963-970

37. Murata Y, Ohteki T, Koyasu S, Hamuro J (2002) IFN-gamma and pro-inflammatory cytokine production by antigen-presenting cells is dictated by intracellular thiol redox status regulated by oxygen tension. Eur J Immunol 32:2866-2873

38. Vilcek J, Henriksen-Destefano D, Siegel D, Klion A, Robb RJ, Le J (1985) Regulation of IFN-gamma induction in human peripheral blood cells by exogenous and endogenously produced interleukin 2. J Immunol 135:1851-1856

39. Sadler AJ, Williams BR (2008) Interferon-inducible antiviral effectors. Nat Rev Immunol 8:559-568

40. Kim KJ, Chaouat G, Leiserson WM, King J, De Maeyer E (1983) Characterization of T-cell-soluble factors modulating the expression of Ia and H-2 antigens on BALB/c B lymphoma cell lines. Cell Immunol 76:253-267
41. Kaplan DH, Shankaran V, Dighe AS, Stockert E, Aguet M, Old LJ, Schreiber RD (1998) Demonstration of an interferon gammadependent tumor surveillance system in immunocompetent mice. Proc Natl Acad Sci USA 95:7556-7561

42. Nagase H, Mao JH, Balmain A (2003) Allele-specific Hras mutations and genetic alterations at tumor susceptibility loci in skin carcinomas from interspecific hybrid mice. Cancer Res 63: 4849-4853

43. Festing MF, Lin L, Devereux TR, Gao F, Yang A, Anna CH, White CM, Malkinson AM, You M (1998) At least four loci and gender are associated with susceptibility to the chemical induction of lung adenomas in $\mathrm{A} / \mathrm{J} \times \mathrm{BALB} / \mathrm{c}$ mice. Genomics 53:129-136

44. Wang H, Teske D, Tess A, Kohlhepp R, Choi Y, Kendziorski C, Moser AR (2007) Identification of novel modifier loci of Apc Min affecting mammary tumor development. Cancer Res 67: $11226-11233$

45. Lee GH, Bugni JM, Obata M, Nishimori H, Ogawa K, Drinkwater NR (1997) Genetic dissection of susceptibility to murine ovarian teratomas that originate from parthenogenetic oocytes. Cancer Res 57:590-593

46. Tripodis N, Demant P (2003) Genetic analysis of three-dimensional shape of mouse lung tumors reveals eight lung tumor shape-determining (Ltsd) loci that are associated with tumor heterogeneity and symmetry. Cancer Res 63:125-131

47. Lee GH, Ogawa K, Nishimori H, Drinkwater NR (1995) Most liver epithelial cell lines from C3B6F1 mice exhibit parentallybiased loss of heterozygosity at the $L c i$ (Liver cell immortalization) locus on chromosome 4. Oncogene 11:2281-2287

48. Cool M, Depault F, Jolicoeur P (2006) Fine allelotyping of Erbb2-induced mammary tumors in mice reveals multiple discontinuous candidate regions of tumor-suppressor loci. Genes Chromosomes Cancer 45:191-202

49. Meruelo D, Offer M, Flieger N (1981) Genetics of susceptibility for radiation-induced leukemia. Mapping of genes involved to chromosomes 1, 2, and 4, and implications for a viral etiology in the disease. J Exp Med 154:1201-1211

50. Santos J, Herranz M, Perez de Castro I, Pellicer A, FernandezPiqueras J (1998) A new candidate site for a tumor suppressor gene involved in mouse thymic lymphomagenesis is located on the distal part of chromosome 4. Oncogene 17:925-929

51. Zhu XX, Kozarsky K, Strahler JR, Eckerskorn C, Lottspeich F, Melhem R, Lowe J, Fox DA, Hanash SM, Atweh GF (1989) Molecular cloning of a novel human leukemia-associated gene. Evidence of conservation in animal species. J Biol Chem 264:14556-14560

52. Cool M, Jolicoeur P (1999) Elevated frequency of loss of heterozygosity in mammary tumors arising in mouse mammary tumor virus/neu transgenic mice. Cancer Res 59:2438-2444

53. Fijneman RJ, Jansen RC, van der Valk MA, Demant P (1998) High frequency of interactions between lung cancer susceptibility genes in the mouse: mapping of Sluc5 to Sluc14. Cancer Res 58:4794-4798

54. Fijneman RJ, Demant P (1995) A gene for susceptibility to small intestinal cancer, ssicl, maps to the distal part of mouse chromosome 4. Cancer Res 55:3179-3182

55. Matsuda Y, Ozaki T, Enomoto H, Saito T, Sakiyama S (1996) Chromosome mapping of the mouse and rat homologs of the human DAN gene, D1S1733E. Mamm Genome 7:709-710

56. Mock BA, Krall MM, Dosik JK (1993) Genetic mapping of tumor susceptibility genes involved in mouse plasmacytomagenesis. Proc Natl Acad Sci USA 90:9499-9503

57. Dorward AM, Shultz KL, Horton LG, Li R, Churchill GA, Beamer WG (2005) Distal Chr 4 harbors a genetic locus (Gctl) fundamental for spontaneous ovarian granulosa cell tumorigenesis in a mouse model. Cancer Res 65:1259-1264 
58. Bliskovsky V, Ramsay ES, Scott J, DuBois W, Shi W, Zhang S, Qian X, Lowy DR, Mock BA (2003) Frap, FKBP12 rapamycinassociated protein, is a candidate gene for the plasmacytoma resistance locus Pctr2 and can act as a tumor suppressor gene. Proc Natl Acad Sci USA 100:14982-14987

59. van Wezel T, Ruivenkamp CA, Stassen AP, Moen CJ, Demant P (1999) Four new colon cancer susceptibility loci, $S c c 6$ to $S c c 9$ in the mouse. Cancer Res 59:4216-4218

60. Bernichtein S, Petretto E, Jamieson S, Goel A, Aitman TJ, Mangion JM, Huhtaniemi IT (2008) Adrenal gland tumorigenesis after gonadectomy in mice is a complex genetic trait driven by epistatic loci. Endocrinology 149:651-661

61. Ko MS, Kitchen JR, Wang X, Threat TA, Wang X, Hasegawa A, Sun T, Grahovac MJ, Kargul GJ, Lim MK, Cui Y, Sano Y,
Tanaka T, Liang Y, Mason S, Paonessa PD, Sauls AD, DePalma GE, Sharara R, Rowe LB, Eppig J, Morrell C, Doi H (2000) Large-scale cDNA analysis reveals phased gene expression patterns during preimplantation mouse development. Development 127:1737-1749

62. Durkin ME, Avner MR, Huh CG, Yuan BZ, Thorgeirsson SS, Popescu NC (2005) DLC-1, a Rho GTPase-activating protein with tumor suppressor function, is essential for embryonic development. FEBS Lett 579:1191-1196

63. Wang D, Lemon WJ, You M (2002) Linkage disequilibrium mapping of novel lung tumor susceptibility quantitative trait loci in mice. Oncogene 21:6858-6865 